\title{
Water policy reforms in Algeria's agriculture: a review and prospects
}

\author{
K. Laoubi \& M. Yamao \\ Graduate School of Biosphere Science, Hiroshima University, Japan
}

\begin{abstract}
Since gaining independence in 1962, several policy reforms have been implemented in Algeria to address the challenges of water scarcity in agriculture. However, questions regarding the implementation and effectiveness of these policy reforms still abound today. The objective of this paper is to review Algeria's water policy reforms in agriculture, focusing on the historical, institutional, resource management, and pricing policy dimensions. The agricultural water sector in Algeria has passed through various stages of policy reform. The first historical stage (1962-1980) was characterized by a lack of institutions, poor water supply, and an absence of demand management strategies. The second stage (1980-1999) was characterized by institutional instability, a lack of accountability, and inadequate and ineffective water supply and demand management. The last stage (2000-present) is characterized by institutional strengthening, a supply-driven approach, and inefficient water management. Overall, the impact of water policy reform on Algerian agriculture, despite recent progress, has been almost negligible in terms of the efficiency and sustainability of its water resource management. Indeed, this review illustrates a gap between principles and practices in sustainable management of water resources. It is now critical that management practices should implement the principles of sustainable and integrated resource management. Priority should be given, but not limited, to the following: establishing coordination structures; developing technical and human capacity and resources at different levels of water management; deploying significant funding resources to sustain existing infrastructures and resources rather than to invest in new water infrastructures; developing a drought contingency plan involving water users; promoting and
\end{abstract}


institutionalizing public-private partnerships; implementing water pricing based on cost recovery principles; enhancing decentralized governance of water resources; promoting participatory irrigation management; developing monitoring capacity for reliable data collection; integrating water management into urban policy planning and management; enhancing water productivity; and using unconventional resources.

Keywords: water policy, agriculture, institutions, water management, water pricing, sustainability.

\section{Introduction}

Irrigated agriculture is the largest user of water resources in Algeria. It contributes to more than $50 \%$ of the total agricultural output. However, Algeria's water resources are scarce and unequally distributed in space and time. The country has among the lowest per capita water supplies in the world. The renewable water resources in Algeria amount to $480 \mathrm{~m}^{3}$ per capita per year. This is below $1000 \mathrm{~m}^{3} /$ capita/year, which is the UN threshold for water poverty. By the year 2050, per capita water availability will fall below the $400 \mathrm{~m}^{3} /$ capita/year, with serious consequences for already-stressed aquifers and natural hydrological systems [1]. In addition to water shortage, increasing population growth, coupled with urbanization and industrialization, and an increasing demand for limited natural resources is placing extreme pressure on the country's water resources. Competition for these finite resources is to be considered with great apprehension; it will be a challenge for the country's future.

Water policy is a critical issue for efficient and sustainable management of water resources in agriculture, and it will become increasingly important as the problem of water scarcity increases. The importance of water policy has been recognized by the United Nations Water Conference (held in Mar del Plata, Argentina, March 14-25, 1997) and has been incorporated into the Millennium Development Goals. Several policy reforms have been implemented in Algeria since independence to address the challenges of water scarcity in agriculture. However, questions regarding the implementation and effectiveness of these policy reforms still abound today. The objective of this paper is to review Algeria's water policy reforms in agriculture, focusing on the historical, institutional, resource management and pricing policy dimensions. This study will discuss critical perspectives on factors, issues and challenges in Algerian agricultural water policies and will provide recommendations for policy improvement towards sustainable agricultural water management.

Following the introduction, Sections two, three and four examine the evolution of Algeria's water policy in agriculture from independence until the present day; describe the institutional, resource management and water pricing changes; and discuss water policy issues, their impact and the achievement of policy objectives at each historical stage. Finally, concluding remarks and recommendations are provided in Section five. 


\section{First stage: 1962 to 1980 - lack of institutions, poor water supply, and absence of demand management strategies}

\subsection{At the institutional level}

After independence in 1962, missions related to the water sector were distributed between the Ministry of Reconstruction, Public Works and Transport and (MRPWT) Ministry of Agriculture and Agrarian Reform (MAAR). The MRPWT was responsible for the greater part and carried out its mission at the level of the ministry itself and through two external services: ITS (Service of Scientific Studies) and the SEGGTH (Service of General Studies and Great Hydraulic Work). The MAAR was responsible for the prerogatives relating to irrigation and rural hydraulics. However, in the 1970s, all missions relating to hydraulics were assigned to one government department: "Secretariat of State for Hydraulics" [2]. Later, between 1978 and 1980, this became the Ministry of Hydraulics, Land Use and the Environment. This period is characterized by a lack of consistent hydraulic policy, resulting in organizational instability within the water sector.

\subsection{At the management level}

In terms of supply management, Algeria's water management was characterized by low mobilization of water resources: the 14 dams built in the colonial era between 1830 and 1962 can no longer hold their initial capacity (i.e., 487 million $\mathrm{m}^{3}$ ) due to silting [3]. Indeed, only 3 dams were built during the period between 1962 and 1980. The total water volume increased from 250 million $\mathrm{m}^{3}$ to only 560 million $\mathrm{m}^{3}$ over the course of two decades. In addition, the financial allocation of the first five-year plan (1970-1974) gave priority to agriculture, which received water from newly planned dams. However, in the second four-year plan (1974-1977), priority was given to meeting the water needs of cities and emerging industry. Agriculture was relegated to second place, and the rural exodus and population explosion pushed the government to reallocate some dams intended for irrigation to supply potable water to large cities. This has led to negative effects on the development of irrigation schemes.

In terms of irrigation management, this period focused mainly on the expansion of irrigation schemes and supply management. Nevertheless, only 13,500 ha were equipped for irrigation in the course of the first plan, even though 51,000 ha had been planned, and only 18,000 ha were equipped in the second plan, even though 111,000 ha had been planned. The irrigated area varied little between 1962 and 1970. However, it decreased from 51,767 ha in 1967 to 49,300 ha in 1980 [3]. In addition, almost exclusive priority was given to largescale hydraulic infrastructure to the detriment of support for alternative irrigation systems such as traditional irrigation techniques and small irrigation schemes [3]. Large-scale irrigation schemes based primarily on dam construction and large water conveyance structures had been introduced by the colonial government. After 1962, the irrigation schemes were managed by a centralized administrative 
subdivision called "Budget Annexe des Irrigations" in the Ministry of Agriculture and characterized by crippling bureaucracy [4]. The financing of projects by local communities ceased at the end of the 1960s [3]. State control led to the complete disappearance of local organizations based on participatory and decentralized initiatives, such as syndicates of water users or irrigation areas [5]. Nearly all hydraulic infrastructures were funded by the State budget [3]. As a result, the irrigation schemes were often poorly managed, the irrigation works were underutilized, and the levels of irrigation intensity were under $60 \%$ [6]. Poor maintenance and management led to an excessive waste of water, estimated at more than $40 \%$ [4]. The irrigation systems deteriorated, and the inadequate budgets allocated to irrigation authorities affected the development and sustainability of the irrigated areas [6].

\subsection{At the water-pricing level}

Pricing structures for irrigation water lag behind those for drinking water. Until 1985, charges for irrigation water were very low; they increased only once between 1972 and 1985 (from US\$0.08 US\$0.016/ $\mathrm{m}^{3}$ in 1972 to US\$0.024 US\$0.033/ $\mathrm{m}^{3}$ plus a fixed charge of US\$39.77 US\$ 39.76/1/s/ha in 1985). It therefore covered only a small portion of the costs. Additionally, insufficient and inefficient use of funds with a low level of recovery charges has contributed to poor operation and maintenance of the water supply. Moreover, there was no positive incentive for irrigation authorities to collect recovery charges because such collections merely reduced their budgetary allocation from the government [6]. At the same time, subsidies from the supplemental irrigation budget were earmarked mostly for constructing new irrigation projects, rather than for maintaining existing ones [7]. At the farm level, lower water charges did not stimulate efficient utilization of water irrigation. Rather, it increased waste by farmers [6]. All these factors have been particularly damaging to irrigation systems, resulting in poor performance and reducing the economic and financial viability of the schemes [4].

\section{Second stage: 1980 to 1999 - institutional instability, lack of accountability, and inadequate and ineffective water supply and demand management}

\subsection{At the institutional level}

Broad powers accompanied by substantial funding were given to the Ministry of Hydraulics. Between 1984 and 1989, the Ministry for Hydraulics became the Department of the Forest and the Environment. In this period, several structures were created to decentralize water management: the National Agency of Dams (ANB) (Decree $\left.\mathrm{n}^{\circ} 85-163,1985\right)$, the National Agency for Water Resources (ANRH) ( $\left.{ }^{\circ} 81-167,1981\right)$, the National Agency for Potable Water and Sanitation (AGEP) (created in June 1985, but operational only in June 1987), the National Agency for the Feasibility Studies of Infrastructure, Development, and 
Implementation of Irrigation Schemes (AGID) ( $\left.\mathrm{n}^{\circ} 87-181,1987\right)$, and the Irrigation Schemes Agencies (OPI) (5 regional and 8 provincial) ( $\mathrm{n}^{\circ} 85-260,29$ October 1985). From 1989 to 1999, the directorates related to irrigation were once again transferred to the Ministry of Agriculture, first through the Secretary of State of Rural Engineering and Agricultural Hydraulics with the Ministry of Agriculture (February to August 1992) and then directly to the Ministry of Agriculture. At that time, however, the Directorates of Statistics, Irrigation and Hydro-agricultural Studies did not have the personnel or the resources to implement their programs [2]. Recruiting adequately trained staff remains an issue due to salary restrictions. The directorates lack basic equipment such as computers and links with rural networks. Such poor resources have affected the performance of the directorates [8]. In addition, during this period, other structures and institutions were created, such as the Watershed Agencies (AHB) (Decree $\mathrm{n}^{\circ}$ 96-100, 6 March 1996), the National Fund for the Integrated Management of Water Resources (Ordinance $n^{\circ} 96-13,15$ June 1996), and the National Council of Water (Executive Decree $n^{\circ}$ 96-472, 18 December 1996).

In terms of regulatory and legislative aspects, several decrees have been enacted. The Water Law (Law $n^{\circ} 83-17,1983$ ) set up principles of water governance, water rights and allocation. The Finance Act of 1992 imposed a tax on pollution and other activities hazardous to the environment. Executive Decree $\mathrm{n}^{\circ}$ 93-163 of 10 July 1993 established an inventory of the degree of pollution of surface water. Executive Decree $\mathrm{n}^{\circ}$ 94-172 of 22 June 1994 amended and supplemented Decree $\mathrm{n}^{\circ}$ 85-260 of 29 October 1985, approving standard specifications for granting concessions for the management, operation and maintenance of irrigation systems. Executive Decree n 94-119 of 1 June 1994 reorganized the status of the irrigation agencies. The Water Law of 1996 (Ordinance $\mathrm{n}^{\circ}$ 96-13 of 15 June 1996 amending and supplementing Act $\mathrm{n}^{\circ}$ 83-17 of 16 July 1983 of the Water Law) introduced the concept of integrated water resource management. Finally, Executive Decree ${ }^{\circ}$ 97-475 of 8 December 1997 laid out works and infrastructure concessions for small- and medium-scale schemes. Nevertheless, water management at the institutional level during this period was characterized by insufficient coordination between the various sectors related to water through the High Council for Water, which was created with the objective of integrating water resource management. The bureaucratic rigidities of the regulations produced inefficiencies both in the conduct of water policy and the management of agencies and public water services. The High Council of Water and various watershed committees had never met since their creation [2], demonstrating the immobility that has characterized the institutions' approach to evaluation and consultation.

\subsection{At the management level}

In terms of supply management, more than 25 dams were built between 1980 and 2000 , creating a total storage capacity of more than 2,848 million $\mathrm{m}^{3}$. Additionally, during this period the total number of boreholes reached 6,242, $33 \%$ of which were used by the agriculture sector. Furthermore, 847 hill reservoirs were built during this period; between 1985 and 1987 alone, 
667 hill reservoirs were built. Total capacity reached 90 million $\mathrm{m}^{3}$ by the end of the 1990s. However, and despite these important investments, the loss of capacity in dams and hill reservoirs was estimated to be about 50\% [9]. Many dams and wells were completed while the downstream infrastructures remained inoperative or without drilling equipment [2]. Downstream infrastructure was incomplete or not started at all, which hindered the profitability of the projects. A logic that favors investment without taking into account operating costs and neglect of infrastructure maintenance took hold. Maintenance work was almost nonexistent. Institutional incentives caused the local governments of Algeria to continue building new dams even when they had not fully exploited existing ones.

In terms of irrigation management, between 1980 and 1984 approximately 40,000 ha of land was equipped for irrigation and 10,000 ha was rehabilitated. At the end of the 1990's, 74,418 ha of land were equipped for irrigation and a total investment of US\$300 million was granted to the development of irrigation schemes between 1980 and 2000. The management of irrigation schemes since 1985 has been conceded to the irrigation agencies under the supervision of the Ministry of Agriculture and Fisheries, which is responsible for operation and maintenance of the irrigation and drainage systems. The agencies were financed through water revenues and state subsidies. The Decree $\mathrm{n}^{\circ}$ 85-260 of 1985, which granted management concession to irrigation agencies (OPI), was not applied in the early years. This led to a confusing situation in which responsibilities were not specified. The installation of non-statutory bodies for the OPI and AGID (Orientation Council) hindered any possibility of dialogue, focus on priorities, or increase of public authorities' awareness of irrigation management issues. It was only after 9 years, in 1994, that the status of the agencies was approved (Executive Decree ${ }^{\circ}$ 94-172, 1994). During this period, the irrigation schemes fell far short of their planned potential: they irrigated smaller areas than they were designed to and deteriorated year by year because they received significantly less investment than was necessary for their maintenance, and they became a drag on state finances. Indeed, the irrigated area in the irrigation schemes actually decreased from 50,336 ha in 1983 to 30,078 ha in 1996, representing less than $20 \%$ of the total equipped area. Among other things, water users lost trust in water managers. As a consequence, relations between the users and the agency deteriorated, resulting in illicit pricking or pumping, illicit drilling in water tables, nonpayment of water charges, disrespect of farming plans and vandalism [10]. Additionally, in years of drought, the water volumes sold were insignificant because agencies did not conduct their maintenance missions properly. The overall system efficiency was estimated at $40 \%$. This low level of system efficiency was compounded by low on-farm water use efficiency, implying that as little as $20 \%$ of the water harnessed for irrigation was actually converted into plant production. In some cases, the exigencies of self-sufficiency policies result in the use of valuable irrigated land for crops with low economic value [8]. 


\subsection{At the water pricing level}

In 1985, the price of irrigated water increased. The price was set to cover operation and maintenance costs and provide financial autonomy to irrigation agencies. However, when the irrigation agencies took responsibility for the irrigation systems, the technical and financial problems became very apparent. Indeed, the irrigation price increased in 1988, 1991 and 1992. The price of water was set by the government without any measure to compensate irrigation agencies [7]. The unsustainability of the irrigation schemes stimulated interest in revising the water pricing policy. Until then, water had not been considered an economic good. With the new Water Code of 1996 (Decree $n^{\circ}$ 96-301, 1996), the water tariff was recognized as an important instrument for conserving water, improving water use efficiency, and providing for the sustainability of irrigation schemes. In fact, irrigation water prices increased in 1998. The new structure of irrigation water pricing involved a two-part tariff, with one part a fixed charge based on amount of water used per hectare (expressed as Da per liter per second per hectare) and the other a volumetric charge. The fixed rate per hectare ranges from $\$ 3.97$ ( $\mathrm{Da} 250$ ) to $\$ 7.59$ ( $\mathrm{Da} 400$ ) per year or per season, and the variable rate ranges from $\$ 0.019$ (Da 1.2) to $\$ 0.022$ (Da 1.25) per cubic meter. However, low water rates and underassessment of irrigated area and water rate demand have deprived the irrigation sector from realizing potential revenue critical for the system's financial sustainability [4]. As a result, lack of maintenance and deterioration of the water supply have decreased the amount of water available for irrigation and led to a significant decrease in the number of water users and area under irrigation [11].

\section{Third stage: 2000 to present - institutional strengthening, a supply-driven approach and inefficient water management}

\subsection{At the institutional level}

In the year 2000, the Ministry of Water Resources was created under Executive Decree $n^{\circ} 2000-324$ of the $25^{\text {th }}$ of October 2000. All directorates related to irrigation were transferred from the Ministry of Agriculture to the Ministry of Water Resources. The latter launched broad institutional reforms. The organization of this sector is set at three levels: a) The central administration, consisting of nine directorates specialized in planning facilities and investment, development and regulation of public services, and general administration, regulation and human resources; $b$ ) The devolved administration, consisting of forty-eight Hydraulics Directorates of Provinces (DHW) responsible for contracting and managing water projects at the municipal level; and c) The intermediary space, consisting of the National Agency for Water Resources (ANRH) and five watershed agencies (ABH) implementing programs for national water resource assessment and integrated water management systems at the watershed. Four public agencies, the National Agency of Dams and Large Transmission Mains (ANBT), the Algerian Water Authority (ADE), the National 
Agency of Sanitation (ONA), and the National Agency of Irrigation and Drainage (ONID), are charged with developing infrastructure and managing water services, sanitation and irrigation. ONID, which previously consisted of multiple administrative public agencies, was transformed into a national state corporation with commercial and industrial management. ONID is now a legal entity with financial autonomy (Decree $\left.\mathrm{n}^{\circ} 05-183,2005\right)$. The structure is responsible for project management, operation and maintenance of irrigation schemes and public service missions. According to Article 16 of Decree $n^{\circ} 05$ 183 , the organization of ONID was conceived in the context of decentralization of management to regional agencies according to the watershed area. The agencies have resources and advisory committees that involve local authorities, professionals and irrigated farmers associations. These regional structures were established taking into account the division selected under the National Plan of Water, implementing the integrated water resource management framework that aims to involve all water sector stakeholders.

Since 2000, water management in agriculture has continued to face multiple issues at several levels [12]. At the scheme level, issues include the weak organization of farmers, misrepresentation of irrigated areas by farmers, nonsettlement of farmer debt to irrigation agencies, late application for water use, poor service delivery, difficulties providing water to state farms (division and competition between farmers), difficulties in estimating the volume consumed, and inadequacy of irrigation system components with regard to farm configuration. At the local level, problems include lack of coordination and conflicts of interest between ONID (irrigation management) and municipalities (urbanization planning). Additionally, the monitoring committee for the irrigation season, which consists of representatives from the DHW, DSA (Agricultural Utilities of the Provinces), Chamber of Agriculture, and Regional ONID, meet rarely or never to prepare for the irrigation season. At the intermediary and ministry level, poor coordination between ANBT and ONID regarding water release (dual use between agricultural and urban users), unreliable data provided by water agencies, lack of coordination between agencies at the Ministry of Water Resources and the departments of other ministries in charge of monitoring, and non-inclusion of watershed agencies in decision-making remain problematic.

\subsection{At the management level}

In terms of supply management, due to the generation of surplus income from the oil boom, the Algerian authorities was able to invest in hydraulic infrastructure and rehabilitation and the extension and development of irrigation schemes. These investments were provided for under the Support Plan for Economic Recovery (PSRE) implemented from 2000 to 2004 and then supplemented by the Complementary Plan for Economic Growth Support (PCSC) from 2005 to 2009. From independence until 2004, the water sector benefited from nearly US\$30 billion in investment. Between 2000 and 2004, public investment in the water sector was US\$8 billion (US\$0.6 billion under 
the PSRE plan), and between 2005 and 2009, it grew to US\$18 billion under the PCSC plan. During this period, 27 dams were constructed and the total storage capacity of the existing 68 dams in Algeria exceed 7,000 million $\mathrm{m}^{3}$ (from 72 dams planned). However, the rate of filling of dams does not exceed $50-70 \%$, leaks in the water supply and irrigation networks are between $40 \%$ and $50 \%$, and 15 of these dams are highly silted. Moreover, increasing supply works, growing populations and associated urbanization, as well as a lack of drought prevention measures, have considerably reduced the allocation of water resources to irrigated land. Indeed, despite the fact that irrigated agriculture is still the largest water user, water allocation for irrigation has dropped from $80 \%$ in the 1960's to around $60 \%$ currently. The growing competition for water among users (urban, agriculture, industry) has resulted in overexploitation of the water table in many agricultural regions of the country. In the Mitidja plain, overexploitation resulted in lowering of the groundwater table by more than 30 meters over the past two decades.

In terms of irrigation management, in 2005, the total area of the irrigation schemes reached 188,009 ha. In the period from 2005 to 2010 , US\$1.1 billion was invested in the development and extension of irrigation schemes, representing $23.5 \%$ of total expenditure in the water sector. Currently, 22 irrigation schemes have been achieved with a total 212,918 ha irrigated by 29 large dams. This represents an average annual extension of 8,840 ha, which is 4 times more than in previous years. In the last decade, less than $40 \%$ of the total equipped area in the irrigation schemes has been irrigated. In 2007, less than $21 \%$ of equipped areas were irrigated. ONID's irrigation management has been very limited and far from satisfactory. Irrigation management issues are exacerbated by a lack of coordination at the institutional and local levels (e.g., ANBT and ONID), which has led to poor monitoring of scarce water supply services; a lack of maintenance; low efficiency; a lack of technical and financial means for intervention in the irrigation system, water allocation system and land reform constraints; inadequate water service provision; inadequate irrigation system components for farm configuration; water theft; acts of vandalism on the hydro-mechanic equipment; weak stakeholder involvement; the indifference of local administrations [12]; and low performance of irrigated farms due to inconsistent irrigated agriculture development policies [13].

\subsection{At the water pricing level}

The government set up a new water law, which was adopted in 2005 (Executive Decree $\left.n^{\circ} 05-14,2005\right)$. The new water code stressed the need for sustainable development and rational use of scarce water resources. Indeed, new water tariffs were implemented: the tariff is set as a fixed rate per hectare ranging from $\$ 3.41$ (Da 250) to $\$ 5.46$ ( $\mathrm{Da} 400$ ) per year or per season. The variable rate ranges from $\$ 0.027$ (Da 2) to $\$ 0.034$ (Da 2.5) per cubic meter. The water price for agricultural use as defined in Decree $n^{\circ} 05-13$ of 9 January 2005 covers the costs of operation and maintenance of the irrigation system, drainage and sanitation and contributes to the financing of their renewal and development. 
According to research conducted on two irrigation schemes, Mitidja East and Mitidja West [12], financial performance assessment demonstrates that regulatory reforms in the water sector intended to promote irrigation agency autonomy and cost recovery have yielded poor results and, moreover, have not achieved the expected goals of sustainable irrigation schemes. Revenues from current water charges did not meet the full operation and maintenance costs, and the maintenance budgets in both schemes were found to be below international and regional norms. The low water price and limited irrigation revenues associated with less investment, lack of maintenance, fee collection constraints, discontinuance of subsidies for irrigation costs, and socio-economic, technical, and institutional factors led to low equilibrium cycles for both schemes and unsustainable water management. Nonetheless, by comparing the water price, water value, and operation and maintenance costs of water delivery, irrigation is still profitable, which makes it possible to increase water prices to recover annual operation costs [14].

\section{Conclusion}

This review shows that the agricultural water sector in Algeria has passed through various stages of policy reform. The first historical stage (1962-1980) was characterized by a lack of institutions, poor water supply, and an absence of demand management strategies. The second stage (1980-1999) was characterized by institutional instability, a lack of accountability, and inadequate and ineffective water supply and demand management. The last stage (2000-present) has been characterized by institutional strengthening, a supply-driven approach, and inefficient water management. Overall, the impact of water policy reforms on the efficiency and sustainability of water resource management in Algerian agriculture has been almost negligible. Nonetheless, the reforms show progress, and the challenges of water scarcity have been addressed, particularly in the last two historical stages, through investment strategy, institutional strengthening, and legislative and regulatory reforms.

The principles of sustainable water management that were introduced in these policy reforms, such as cost recovery, resource use efficiency, conservation, decentralization, equitable allocation of resources, and integrated resource management, were not sufficiently implemented. Indeed, this review illustrated a gap between principles and practices in the sustainable management of water resources.

Water in Algeria is already a scarce resource, and it will become even scarcer in the future. Poor management in the water sector is symptomatic of poor management in the overall agricultural sector, which complicates and aggravates the problem and, as a consequence, will threaten the future food security of the country. This emphasizes the need for the highest efficiency in the use and management of water resources and public awareness of the importance of its conservation. It is critical that management practices should implement the principles of sustainable and integrated resource management. Key priorities should be given to the following: 
- Establishing coordination structures at national, regional and local levels that involve diverse stakeholders with various objectives (water users, industry, urban-dwellers, different administrative levels, water agencies, watershed agencies and all entities/groups that have a stake in using or managing water) to avoid conflicts, to improve efficiency and coherence in decision-making for sustainable water management.

- Developing technical and human capacity and resources at different levels of water management, including within water agencies, departments, and the Ministry of Water Resources.

- Developing monitoring capacity to improve reliable, up-to-date data collection on the quality and quantity of water resources and current and projected demand for water.

- Integrating water management into urban policy planning and management.

- Deploying significant funding resources to sustain the existing infrastructures and resources through a systematized program of repair, maintenance, and rehabilitation to improve performance, to increase efficiencies, and reduce water leakage. This implies an active use of policies for conserving water. Water efficiency is the most cost-effective source of reliable water supply.

- Generalizing the use of water meters to improve accountability and implementing water pricing based on cost recovery principles with the objective of full recovery of operation and maintenance costs.

- Developing a drought contingency plan involving water users to manage and monitor drought conditions, to determine water allocation programs, to conserve the available water supply in extreme and extended drought conditions through public information, measures and management practices, and to minimize the adverse impacts of water supply shortages.

- Promoting and institutionalizing public-private partnerships in irrigation development and management.

- Enhancing decentralized governance of water resource through the promotion and empowerment of water users' associations.

- Promoting participatory irrigation management by involving and associating farmers in the planning, operation and maintenance of irrigation systems through the development of institutional and legal tools for effective irrigation management.

- Enhancing water productivity through: $a$ ) effective agricultural policies and institutions; b) water-saving technologies and management strategies; $c$ ) improvement of agricultural practices; $d$ ) adjustment of irrigation system components to the appropriate farm configuration; $e$ ) education, awareness campaigns and mentoring; f) capacity development for both irrigation agency staff and farmers; and $g$ ) promotion of irrigated agricultural extension programs.

- Supporting water police enforcement activities and the involvement of the irrigation agencies in groundwater management activities.

- Using unconventional resources; wastewater reuse is necessary to balance supply and demand and to secure the water supply. 


\section{References}

[1] World Bank, Making the most scarcity: Accountability for better water management in the Middle East and North Africa. MENA Development Report 41113, World Bank, Washington DC, 2007.

[2] CNES, L'eau en Algérie: Le grand défi de demain. Conseil National Economique et Social, $15^{\text {th }}$ Session, National Report, Algiers, May 2000.

[3] Pérennès, J.J., L'eau et les hommes au Maghreb. Karthala, Paris, pp. 179184, 1993.

[4] Benmouffok, B., La prise en charge de l'irrigation en Algérie. Paper presented at 4th forum of La Gestion de la Demande en Eau, Cairo, 2-4 February, 2003.

[5] CNES, Problématique de Développement Agricole: Eléments pour un débat national. Conseil National Economique et Social, $14{ }^{\text {th }}$ Session, National Report, Algiers, November 2000.

[6] Cleaver, K., The agricultural development of Algeria, Morocco, and Tunisia: A comparison of strategies for growth. Staff Working Paper $n^{\circ}$ SWP 552, World Bank, Washington DC, 1982.

[7] Salem, A., Water pricing experiences: An international perspective. World Bank technical paper $\mathrm{n}^{\circ} 386$. World Bank, Washington DC, pp. 13-16, 1997.

[8] World Bank, Algeria: Review of agricultural policies and agricultural services 1987-1993. Report n 12534, World Bank, Washington DC, 1994.

[9] Boudjadja, A., Messahel, M. \& Pauc H., Ressources hydriques en Algérie du nord. Revue des Sciences de L'eau, 16 (2), pp. 285-304, 2003.

[10] Messahel, M. \& Benhafid, M.S., Aménagements hydro agricoles: Situation actuelle et perspectives de développement en Algérie. Options Méditerranéennes Séries B, $\mathrm{n}^{\circ}$ 48, Montpellier, pp. 83-95, 2004.

[11] Laoubi, K. \& Yamao, M., Water pricing and the performance evaluation of irrigation schemes: The case of the Hamiz Irrigation scheme in Algeria. Journal of Rural Economics, Special Issue, Tokyo, pp. 565-572, 2005.

[12] Laoubi, K. \& Yamao, M., Irrigation schemes management in Algeria: An assessment of water policy impact and perspectives on development (Chapter 10). Water Resources Management V, ed. C.A. Brebbia \& V. Popov, WIT Press: Southampton, UK, pp. 503-514, 2009.

[13] Laoubi, K. \& Yamao, M., A typology of irrigated farms as a tool for sustainable agricultural development in irrigation schemes: The case of the East Mitidja scheme, Algeria. International Journal of Social Economics, 36 (8), pp. 813-831, 2009.

[14] Laoubi, K. \& Yamao, M., Algerian irrigation in transition; effects on irrigation profitability in irrigation schemes: The case of the East Mitidja scheme". Proc. of the Int. Conf. On Sustainable Economic Development, World Academy of Science, Engineering and Technology 36, Thailand, pp. 1079-1083. 2008. 